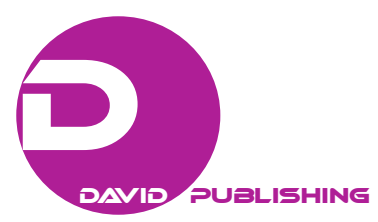

\title{
Audit Opinion: Model Value of the Firm State-Owned Business Enterprises Indonesia*
}

\author{
Hwihanus, Tri Ratnawati \\ University of 17 Agustus 1945 Surabaya, Surabaya, Indonesia \\ Indrawati Yuhertiana \\ University of Pembangunan Nasional Veteran Jawa Timur, Surabaya, Indonesia
}

\begin{abstract}
This study aimed to assess and analyzed the influence of micro and macro fundamental, ownership structure, financial performance, and auditor's opinion on the value of the company in State Owned Enterprises considering that 51\% of shareholding is fully owned and controlled by the government so management has some rights in decision making. The interest of researchers in observing State Owned Enterprises on interest ownership interest in investors and potential investors compared to private companies that fluctuate in accordance with state economic conditions and government decisions that provide sentiment for stocks. Research population at 20 State Owned Enterprises listed on Indonesia Stock Exchange. This research method used purposive sampling with 12 companies in 2010-2015. Data analysis techniques in this study used Partial Least Square consists of Inner model, Outers model, and Weight relation. The result of analysis of hypothesis test of research showing all test accepted with significant level 5\% influence equal to 1.960 except macro fund influence 0.0031421 and not significant equal to 1.914374 so rejected (H5) and macro fundamentals have effect 0.040271 and not significant equal 1.674420 thus rejected (H7).

Keywords: micro-fundamentals, macro fundamental, ownership structure, financial performance, auditor opinion, value of the firm
\end{abstract}

\section{Introduction}

State Owned Enterprises (SOEs) is a government company of the Republic of Indonesia. All activities of SOEs are always related to government policies that can weaken activity information to investors outside the government. The purpose of investors to have SOE shares hoping to get capital gains and prospects according to the state of the country's economy and government decisions.

Research with objects of SOEs has not been much studied, mostly researching on non-governmental companies that go public with the topic of corporate value that is reflected in the stock price. The researcher is

\footnotetext{
* Acknowledgments: Directorate of Community Service Research (DRPM), Ministry of Research, Technology and Higher Education (Kemristekdikti).

Hwihanus, SE, MM, CMA, Economic Faculty and Business, University of 17 Agustus 1945 Surabaya, Surabaya, Indonesia.

Tri Ratnawati, Prof., Dr., Ak., CA, CPA, Economic Faculty and Business, University of 17 Agustus 1945 Surabaya, Surabaya, Indonesia.

Indrawati Yuhertiana, Dr., MM, Ak., CA, CMA, Economic and Business Faculty, University of Pembangunan National Veteran Jawa Timur, Surabaya, Indonesia.

Correspondence concerning this article should be addressed to Economic and Business Faculty, University of 17 Agustus 1945 Surabaya, Jl. Semolowaru 45 Surabaya 60118, Indonesia.
} 
interested to observe SOEs which is prospective with share price SOEs and the Composite Stock Price Index (IHSG) in the capital market fluctuate in the state of the country's economy and government decisions that provide sentiment for the stock market compared to the price of shares of non SOEs. The share price of SOEs and IHSGs listed on the Indonesia Stock Exchange (IDX) is shown on December, 31 2010-December, 312016 shown in the following figure.

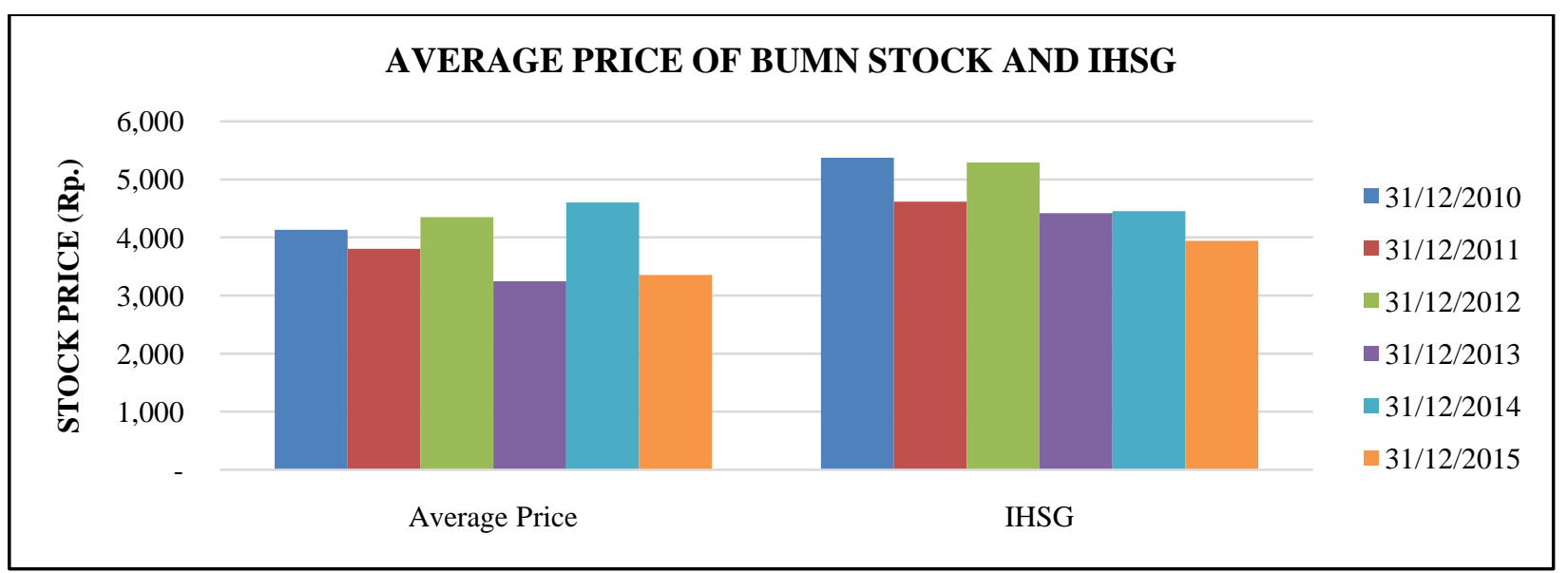

Figure 1. List of share price of State Owned Enterprises in Indonesia Stock Exchange. Source: Data processed.

The high stock price in Figure 1 above will give an idea of optimizing the value of the company on the welfare and prosperity of its owner (Fama, 1978; Claude \& Labelle, 2012; McConnell \& Muscarela, 1985). The price of shares as a representation of corporate value is determined internal and external factors of the company. Internal and external factors are fundamental factors that are often used as a basis by investors in the capital market to make investment decisions. In addition to fundamental factors, technical factors are also factors that can affect the price of shares that are technical and psychological.

Fundamental macro factors are uncontrollable which include economic, social, cultural, demographic, and environmental factors, political power, government, and law, technology, and competition (David, 2003). Micro fundamental factors are controllable companies and are grouped into company policies. The company's performance factor is profit in the form of corporate dividends expected in the future (Fuller \& Farrell, 1987). The company's policy factors include funding, investment, and dividend policies. The funding policy is projected with the financial leverages, the investment policy is proxy by capital expenditure, and dividend policy is proxy by manager incentive, while the company performance factor is emphasized on the financial performance aspect which is proxy by Return on Assets (ROA).

SOEs involve many stakeholders, the owners (stockholders), and managers. Agency relationships as contracts by one or more of the principals include the agent in the service of interests that include the authority of delegating decision making to agents (Jensen \& Meckling, 1976).

Auditor opinion on financial report becomes one of the important considerations for investors in making investment decisions. The role of auditors is very reliable as an intermediary of the interests of investors and corporate interests as a provider of financial statements. Audit is one of the steps taken to reduce agency conflict in collecting and evaluating objective evidence on management assertions, determining the level of conformity of the assertion with predetermined criteria, and delivering the results to the parties concerned.

This conceptual research examines theoretical models relating to corporate responsibility in agency theory 
and incorporates manager behavior in decision making in an effort to improve the profitability and value of SOE companies on micro fundamentals, macro fundamentals, ownership structures, financial performance, and auditor's opinion on value of the firm.

\section{Literature Review}

\section{Management Accounting}

Management accounting is a systematic accounting that links the provision and use of management information in an organization with the aim of providing standards to management in decision making. Management accounting helps the preparation of planned and effective budget, helps the process of supervision and recognition, and overcomes the problems of irregularities that occur in the company.

Management accounting as an accounting type is a financial processing system used to generate information for the interests of internal users of the organization while management accounting as a type of quantitative information uses money as a unit of measure in the implementation of corporate management.

\section{Agency Theory}

Jensen and Meckling (1976) describe agency relations as a principal contract involving agents in performing some services by delegating decision-making powers to agents. Agency theory assumes that all shareholders act on their own behalf and are interested in the company's financial results in large dividend payouts, while management receives satisfaction in the form of high financial compensation and the conditions that accompany the relationship. Differences in the interests of shareholders and management lies in the maximization of the utility of shareholders (principal) with the constraints of benefits (utility) and incentives that will be accepted by the manager (agent).

The basis of agency theory is divided into assumptions of human nature, organizational assumptions, and information assumptions. The assumption of human nature emphasizes that human beings have self-interest, and have bounded rationality and risk aversion. Organizational assumptions emphasize the conflict between members of the organization and information asymmetry between the principal and the agent, while the information assumption emphasizes that the information of commodity goods can be traded.

The conflict of interest of agents and principals in achieving prosperity is due to the information asymmetry between owners and managers. Managers have internal information that is relatively more and faster than external parties, such as investors and creditors. This provides an opportunity for managers to use the information they know to manipulate financial reporting in maximizing their prosperity (Cheng, Lee, \& Yang, 2012).

\section{Signaling Theory}

Signaling theory emphasizes the importance of corporate information to investment decisions. Morris (1987) argues that the asymmetric problem of information in the market can be reduced by giving more information signals to other parties owned by the company (management). If the information contains a positive value (good news), it is expected that market participants accept (Spence, 1973).

\section{Stakeholder Theory}

Stakeholder theory states that a company is not an entity operating for its own sake but must provide benefits to its stakeholders. The goal is to assist management in enhancing value creation for the various activities undertaken and minimizing the losses that arise for stakeholders. Excess stakeholder theory lies in the focus of theory in ways that companies use in managing stakeholders to benefit the company. Thus, the existence of a 
company is strongly influenced by stakeholder support to the company.

\section{Legitimacy Theory}

Legitimacy (Dowling \& Pfeffer, 1975) is a desirable entity action according to socially evolving norms, values, and belief systems. Legitimacy is considered important for the company in determining the company's future development strategy because of a social contract implied between social institutions and society.

Company legitimacy will be obtained if there are similarities between the results expected by the community from the company and no demands from the community.

Companies can make social sacrifices as a reflection of the company's attention to society so as not to legitimize the gap between the two. The legitimacy of the gap is due to changes in corporate performance but people's expectations are unchanged, the company's performance changes but people's expectations are unchanged, and the company's performance and expectations of the company's performance are changing in different directions.

\section{Macro Fundamentals}

Macro fundamental factors derived from outside the company and the nature of uncontrollable can be economic, environmental, political, legal, social, cultural, security, education, and others that cannot be controlled by the company but the effect is very big if there is a change. External economic factors of firms with inflation indicators, interest rates, exchange rates, and economic growth may affect market risk or systematic risk (Brigham \& Houston, 2015).

These macro-economic conditions have received serious attention from analysts and capital market actors in deciding which investments will be taken by looking at the prediction of inflation movement, interest rate, exchange rate, and economic growth and potentially to increase or decrease investment in real sector and impact on market performance capital including the company.

\section{Micro Fundamentals}

The company's micro fundamental are used in the future development of the company. Management requires several policies that must be taken for the sake of corporate survival of investment decisions, funding decisions, and dividend policies.

The decision to invest funds owned by a person or company in tangible assets or will not gain profit in the future. Investment activities undertaken by the company are expected to provide an optimal profit and can be reused for investment activities or distributed to shareholders in the form of dividends.

The funding decision is a financial structure decision consisting of own capital, short-term debt, and long-term debt that affect the value of the company declared trade off theory. Pecking order theory establishes funding decisions for managers to choose retained earnings and debt as the primary choice and issuance of shares as a last resort.

The dividend policy is a dividend payment decision by the company to shareholders or retained for future development needs of the company. In this study, researchers used indicators Dividend Payout Ratio (DPR), Current Ratio (CR), Debt Equity Ratio (DER), and Company size.

\section{Ownership Structure}

The ownership structure clarifies the owner's commitment to save the company (Wardhani, 2006). Ownership structure is believed to affect the performance of the company in achieving the company's goal of 
maximizing value of the firm. The successful implementation of corporate governance is inseparable from the ownership structure reflected through stock instruments and debt instruments so that ownership structure can be reviewed in case of agency problems. There are several things to consider in the ownership structure, among others: (1) The ownership of a small part of the company by management influences the tendency to maximize shareholder value rather than merely achieving the company's objectives, (2) concentrated ownership gives incentives to majority shareholders to participate active in the company, and (3) the identity of the owner determines the priority of the company's social objectives and the maximization of shareholder value.

The ownership structure in Indonesia has different characteristics from companies in other countries. Most companies in Indonesia have a tendency to be concentrated as founders and sit on boards of directors or commissioners, and in addition agency conflicts can occur between managers and owners and also majority and minority shareholders as revealed by Jensen and Meckling (1976) that the agency conflict arises as a result of the separation between ownership and control of the firm, where in the agency theory described the parties involved in the company, i.e., managers, owners of companies, and creditors will behave, because basically they have different interests.

\section{Financial Performance}

Performance is a performance achievement of a company's activities in realizing the goals, goals, mission, and vision of the organization in strategic planning of a company. Performance also measures the success of a company in getting a profit. Company performance is important and must be achieved every company as a reflection of the company's ability to manage and allocate resources owned. The main purpose of performance appraisal is to motivate employees to achieve organizational goals and adhere to the standards of conduct set by the company in order to distinguish the desired actions and results.

Performance measurements performed over a given period are useful for assessing the progress the company has made, producing useful information in management decision making, and creating company value. Company performance is divided into the company's operational performance and market performance. Company's operational performance is measured by looking at the company's financial statements by using activity ratio in the form of receivable turnover, asset turnover, leverage in the form of DTA and profitability of GPM.

\section{Auditor Opinion}

Auditor opinion is part of audit report given by auditor through audit stage. The auditor's report (Boynton \& Raymon, 2005) is a formal tool used by auditors to communicate financial statements to interested parties, i.e., owners of companies and investors.

Types of auditors' opinions are: (1) unqualified opinion, (2) unqualified opinion with explanatory language; (3) fair opinion with the exception (qualified opinion); (4) adverse opinion (opinion), and (5) opinion not disclaimer.

An audit report related to the going concern called going concern audit opinion is used to provide early warning to shareholders in order to avoid making mistakes. This decree is stipulated in PSA 29 Paragraph 11 which states that major doubts in the ability of the business unit to maintain the going concern and the auditor shall add an explanatory paragraph in the audit report although it does not affect the unqualified opinion.

A going concern audit opinion is an opinion that indicates significant uncertainty over the company's ability 
to continue the business and must be explicitly stated in the auditor's opinion by providing code 1 and code 0 if the auditor has no doubt over the company's ability to continue the business. Giving opinion to the company, auditors with reputable public accounting firm (KAP) perform quality audit processes that are independent and objective by issuing modified opinion on companies experiencing financial distress. KAP affiliates are used and trusted by state-owned companies and are known for the big four of KAP PricewaterhouseCoopers, Deloitte Touche Tohmatsu, Erns Young Global, and KPMG International.

Researchers use the indicators of going concern audit opinion, KAP big four, Return on Assets (ROA), and Return on Equity (ROE)

\section{The Value of the Firm}

The book value in the financial statements is the limitation of measuring value of the firm and being used to invest. Investors use perceptions of investments based on stock prices. The main purpose of the company (Sirmon, Hitt, \& Ireland, 2007) is to maximize the value of a firm that is not just maximizing the company's profit. This statement is accepted on the basis of (1) considering the effect of time on the value of money, (2) considering the risks to the firm's revenue stream, and (3) the quality of the expected cash flow of funds in the future.

Value of the Firm is defined as the market value (Bowman \& Ambrosini, 2007; Luo, Zhang, \& Duan, 2013) that can provide maximum shareholder wealth if the company's stock price increases. Investors hand over their capital management to corporate professionals. Value of the firm is the price paid by the prospective buyer. Determining the value of the firm, researchers use measurement tools such as Tobin's Q, Price Book Value (PBV), Pricing Earning Ratio (PER), and Earning Per Share (EPS).

\section{Research Hypothesis}

The research hypothesis can be done as follows:

(1) Micro fundamentals have a significant effect on Ownership Structure.

(2) Macro Fundamentals have a significant effect on Auditor Opinion.

(3) Micro Fundamentals have a significant effect on Financial Performance.

(4) Macro Fundamentals have a significant effect on Financial Performance.

(5) Micro Fundamentals have a significant effect on Ownership Structure.

(6) Macro Fundamentals have a significant effect on Auditor Opinion.

(7) Macro Fundamentals have a significant effect on Value of the Firm.

(8) Micro Fundamentals have a significant effect on Value of the Firm.

(9) Ownership Structure has a significant effect on Financial Performance.

(10) Financial Performance has significant effect on Opinion Audit Going Concern.

(11) Ownership Structure has a significant effect on Value of the Firm.

(12) Financial Performance has a significant effect on Value of the Firm.

(13) Opinion Audit Going Concern has a significant effect on Value of the Firm.

\section{Research Methods}

\section{Sample Research}

The sampling technique used purposive sampling method with 12 of 20 SOEs listed on the Indonesia 
Stock Exchange with observations from 2010 to 2015, namely PT Indofarma (Persero) Tbk, PT Kimia Farma (Persero) Tbk., PT Perusahaan Gas Negara (Persero) Tbk., PT Adhi Karya (Persero) Tbk., PT Pembangunan Perumahan (Persero) Tbk., PT Wijaya Karya (Persero) Tbk., PT Aneka Tambang (Persero) Tbk., PT Bukit Asam (Persero) Tbk. PT Timah (Persero) Tbk., PT Semen Indonesia (Persero) Tbk., PT Jasa Marga (Persero) Tbk., and PT Telekomunikasi Indonesia (Persero) Tbk.

\section{Variables and Indicators}

Variables and indicators used in this study are as follows:

Table 1

Variables, Notations, and Indicators of Research

\begin{tabular}{|c|c|c|c|}
\hline Variables & & Notation & Indicator \\
\hline \multirow{8}{*}{$\begin{array}{l}\text { Independent } \\
\text { Variable }\end{array}$} & \multirow{4}{*}{ Micro Fundamentals $\left(\mathrm{X}_{1}\right)$} & $\mathrm{X}_{1.1}$ & Current Ratio (CR) \\
\hline & & $\mathrm{X}_{1.2}$ & Dividend Payout Ratio (DPR) \\
\hline & & $\mathrm{X}_{1.3}$ & Dividend Equity Ratio (DER) \\
\hline & & $\mathrm{X}_{1.4}$ & Company Size (FZ) \\
\hline & \multirow{4}{*}{ Macro Fundamentals $\left(\mathrm{X}_{2}\right)$} & $\mathrm{X}_{2.1}$ & Product Domestic Bruto (PDB) \\
\hline & & $\mathrm{X}_{2.2}$ & Interest Rate (SB) \\
\hline & & $\mathrm{X}_{2.3}$ & Inflation \\
\hline & & $\mathrm{X}_{2.4}$ & Exchange Rate \\
\hline \multirow{14}{*}{$\begin{array}{l}\text { Intervening } \\
\text { Variable }\end{array}$} & \multirow{5}{*}{ Ownership Structure $\left(\mathrm{Z}_{1}\right)$} & $\mathrm{Z}_{1.1}$ & Institutional \\
\hline & & $\mathrm{Z}_{1.2}$ & Foreign \\
\hline & & $\mathrm{Z}_{1.3}$ & Public \\
\hline & & $\mathrm{Z}_{1.4}$ & Government \\
\hline & & $\mathrm{Z}_{1.5}$ & Managerial \\
\hline & \multirow{5}{*}{ Financial Performance $\left(\mathrm{Z}_{2}\right)$} & $\mathrm{Z}_{2.1}$ & Account Receivable Turnover (Per Piu) \\
\hline & & $\mathrm{Z}_{2.2}$ & Fixed Asset Turnover (Per AT) \\
\hline & & $\mathrm{Z}_{2.3}$ & Debt to Asset (DTA) \\
\hline & & $\mathrm{Z}_{2.4}$ & Gross Profit Margin (GPM) \\
\hline & & $\mathrm{Z}_{2.5}$ & Inventory Turnover (PPS) \\
\hline & \multirow{4}{*}{ Auditor Opinion $\left(\mathrm{Z}_{3}\right)$} & $\mathrm{Z}_{3.1}$ & Four Public Accounting Firm (4KAP) \\
\hline & & $\mathrm{Z}_{3.2}$ & Opinion Audit Going Concern (OAGC) \\
\hline & & $\mathrm{Z}_{3.3}$ & Return on Equity (ROE) \\
\hline & & $Z_{3.4}$ & Return on Assets (ROA) \\
\hline \multirow{4}{*}{ Dependent Variable } & \multirow{4}{*}{ Value of the Firm $\left(\mathrm{Y}_{1}\right)$} & $\mathrm{Y}_{1.1}$ & Earnings per Share (EPS) \\
\hline & & $\mathrm{Y}_{1.2}$ & Price Book Value (PBV) \\
\hline & & $\mathrm{Y}_{1.3}$ & Tobin's Q \\
\hline & & $\mathrm{Y}_{1.4}$ & Price Earnings Ratio (PER) \\
\hline
\end{tabular}

Source: Data processed.

\section{Conceptual Framework}

The relationship between research variables can be described conceptual framework as follows:

\section{Analysis Technique}

The analysis of this research uses partial least square application in estimating path model using latent construct with multiple indicator. 


\section{Results and Discussion}

\section{Testing Research Model}

This study uses the limit factor of loading factor by reflecting the indicator based on the relation between each item score with construct score with the measurement scale which is considered enough at the loading value of 0.5 so that the measurement scale that does not meet the provision is done by dropping.

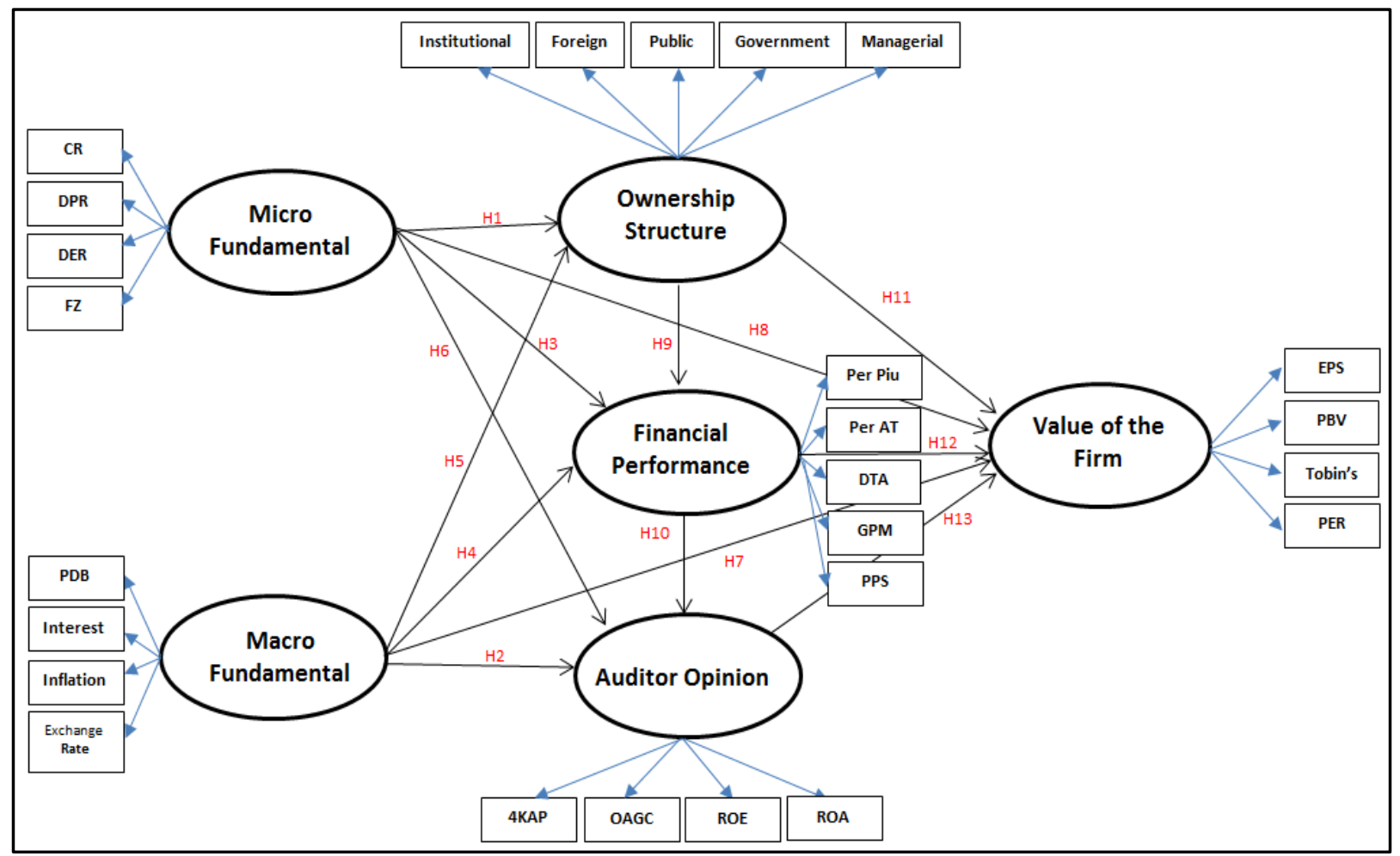

Figure 2. Conceptual framework for research and indicators.

Determining the relationship between variables required statistical testing with a significance level of $95 \%$ $(\alpha=0.05)$ and a t-table value of 1.96 would accept the overall alternative hypothesis in the following table.

Table 2

Test Results of PLS Analysis

\begin{tabular}{|c|c|c|c|c|c|c|c|}
\hline $\mathrm{Ha}$ & Variable Relations & $\begin{array}{l}\text { Original } \\
\text { Sample }(\mathrm{O})\end{array}$ & $\begin{array}{l}\text { Sample } \\
\text { Mean (M) }\end{array}$ & $\begin{array}{l}\text { Standard } \\
\text { Deviation } \\
\text { (STDEV) }\end{array}$ & $\begin{array}{l}\text { Standard Error } \\
\text { (STERR) }\end{array}$ & $\begin{array}{l}\text { T Statistics } \\
(|\mathrm{O} / \mathrm{STERR}|)\end{array}$ & Significant \\
\hline $\mathrm{H} 1$ & $\begin{array}{l}\text { X1 Micro Fundamental -> } \\
\text { Z1 Ownership Structure }\end{array}$ & -0.383025 & -0.382355 & 0.016815 & 0.016815 & 22.779295 & Significant \\
\hline $\mathrm{H} 2$ & $\begin{array}{l}\text { X2 Macro Fundamental -> } \\
\text { Z3 Auditor Opinion }\end{array}$ & -0.107777 & -0.104853 & 0.024502 & 0.024502 & 4.398692 & Significant \\
\hline $\mathrm{H} 3$ & $\begin{array}{l}\text { X1 Micro Fundamental -> } \\
\text { Z2 Financial Performance }\end{array}$ & 0.680669 & 0.681263 & 0.010664 & 0.010664 & 63.829269 & Significant \\
\hline $\mathrm{H} 4$ & $\begin{array}{l}\text { X2 Macro Fundamental -> } \\
\text { Z2 Financial Performance }\end{array}$ & -0.110607 & -0.113912 & 0.015591 & 0.015591 & 7.094132 & Significant \\
\hline H5 & $\begin{array}{l}\text { X2 Macro Fundamental -> } \\
\text { Z1 Ownership Structure }\end{array}$ & -0.040784 & -0.040248 & 0.021304 & 0.021304 & 1.914374 & $\begin{array}{l}\text { No } \\
\text { Significant }\end{array}$ \\
\hline H6 & $\begin{array}{l}\text { X1 Micro Fundamental -> } \\
\text { Z3 Auditor Opinion }\end{array}$ & 0.262154 & 0.259507 & 0.027943 & 0.027943 & 9.381600 & Significant \\
\hline
\end{tabular}


Table 2 to be continued

\begin{tabular}{|c|c|c|c|c|c|c|c|}
\hline H7 & $\begin{array}{l}\text { X2 Macro Fundamental -> } \\
\text { Y Value of the Firm }\end{array}$ & 0.040271 & 0.034112 & 0.024022 & 0.024022 & 1.676420 & No Significant \\
\hline H8 & $\begin{array}{l}\text { X1 Micro Fundamental -> } \\
\text { Y Value of the Firm }\end{array}$ & -0.148095 & -0.144444 & 0.025388 & 0.025388 & 5.833335 & Significant \\
\hline H9 & $\begin{array}{l}\text { Z1 Ownership Structure -> } \\
\text { Z2 Financial Performance }\end{array}$ & 0.055217 & 0.054174 & 0.015350 & 0.015350 & 3.597260 & Significant \\
\hline H10 & $\begin{array}{l}\text { Z2 Financial Performance -> } \\
\text { Z3 Auditor Opinion }\end{array}$ & 0.435493 & 0.436291 & 0.019478 & 0.019478 & 22.358282 & Significant \\
\hline H11 & $\begin{array}{l}\text { Z1 Ownership Structure -> } \\
\text { Y Value of the Firm }\end{array}$ & -0.342565 & -0.344615 & 0.013485 & 0.013485 & 25.404193 & Significant \\
\hline H12 & $\begin{array}{l}\text { Z2 Financial Performance -> } \\
\text { Y Value of the Firm }\end{array}$ & 0.246374 & 0.241953 & 0.014497 & 0.014497 & 16.994578 & Significant \\
\hline H13 & $\begin{array}{l}\text { Z3 Auditor Opinion -> } \\
\text { Y Value of the Firm }\end{array}$ & 0.470826 & 0.471194 & 0.021704 & 0.021704 & 21.693100 & Significant \\
\hline
\end{tabular}

Source: Data processed.

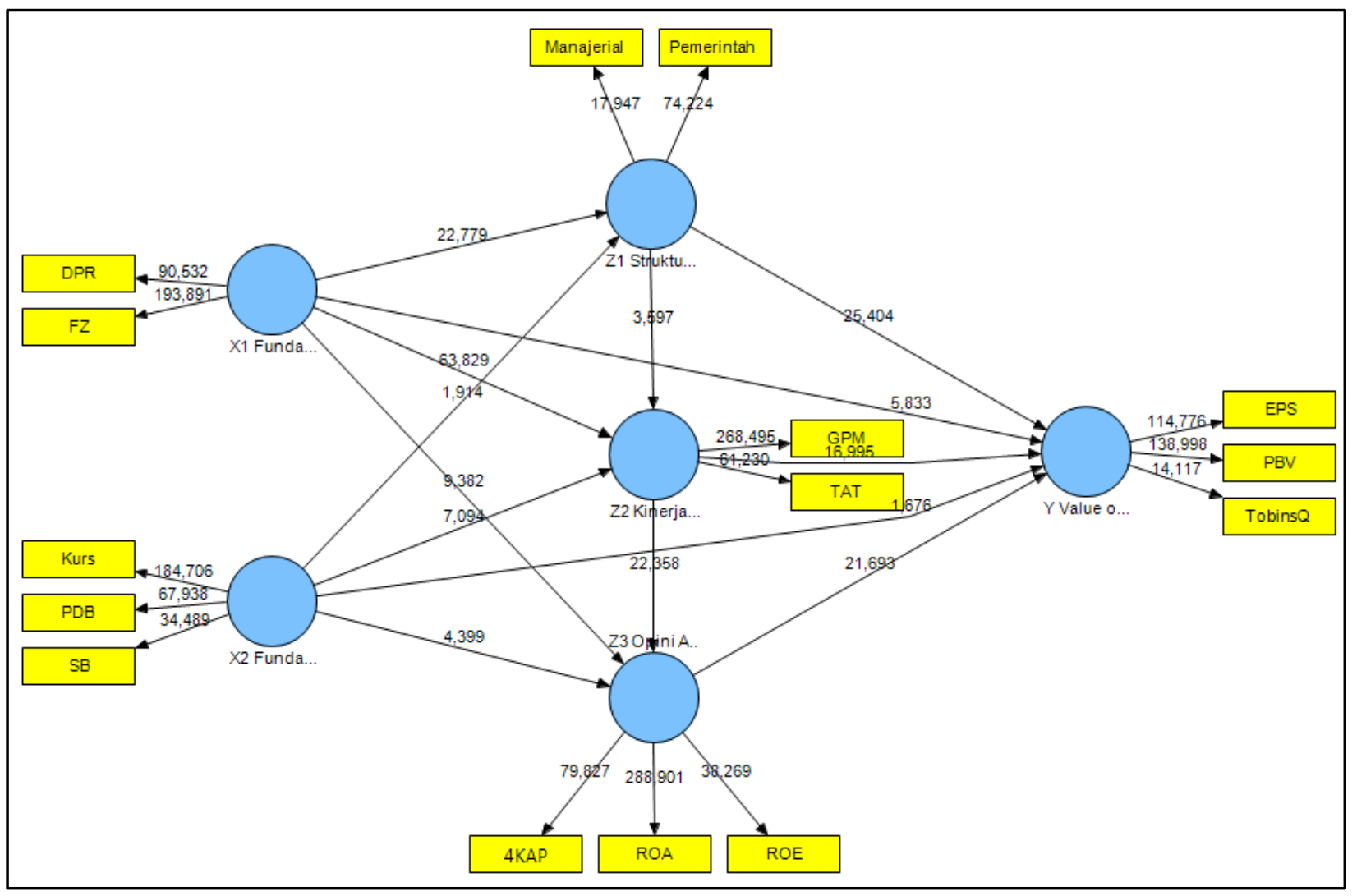

Figure 3. Structural model test results (inner model).

\section{Proposition}

Micro fundamentals with DPR and company size indicators have a negative and significant influence on ownership structure with indicators of managerial and government ownership which means that any management policy taken by the company will not affect the company's ownership structure in managerial and government.

Macro fundamentals with foreign currency exchange rates, GDP, and interest rates have a negative and significant influence on auditor opinion with indicators of ROE, ROA, and Big Four Public Accounting Firms. The country's macro conditions negatively affect each management's decision to obtain profits from the equity 
held and stated through the accountant's opinion on the report being examined so that any opinions given by the accounting firm do not affect macro policies.

Micro fundamentals with DPR indicators and company size have a positive and significant impact on financial performance with GPM indicators and fixed asset turnover provided by management as company managers. Management policy contributes to the financial performance where each policy carried out will support the company's performance, including providing benefits to shareholders.

Macro fundamentals have a negative and significant impact on financial performance. Macro policies that occur in foreign exchange rates, interest rates, and GDP have a negative effect on the financial performance of the company so that no matter how large a country's macro changes will not affect management's financial performance. Researchers reject Claude et al. (2012) and Eduardus (1997) research which states that macro fundamental factors are very important factors related to company performance and value. Researchers accept the Opod study (2015) which states that inflation, interest rates, exchange rates, economic growth have no significant effect on financial performance.

The fundamental macro with foreign exchange rates, interest rates, and GDP has a negative and insignificant influence on the ownership structure with indicators of managerial and government ownership even though the macro conditions that occur do not affect the ownership structure even though the largest ownership is held by the government.

Micro fundamentals with DPR and company size have a positive and significant impact on the auditor's opinion with indicators of ROE, ROA, and Big Four of the Public Accounting Firm. Every management decision made will influence the auditor's opinion conducted by the accounting firm.

Macro fundamentals have a positive and insignificant effect on indicators of foreign exchange rates, interest rates, and gross domestic income will increase the value of the company in EPS, PBV, and Tobin's Q. Researchers accept the studies of Claude et al. (1996), Eduardus (1997), and Syahib (2000) which show that macro fundamental factors have a positive impact on firm value so that every macro decision will have an impact on the company's value and is insignificant.

Micro fundamentals with company size indicators and DPR have a negative and significant influence on the firm value on EPS, PBV, and Tobin's Q. Researchers reject Putra's research (2014) showing the EPS and DER ratios have no effect on firm value. Researchers reject Arvianto and Sabi (2014) which states that the micro fundamental factor is the value of the company with the condition of the company's fundamental factors, giving a strong influence on the value of the company.

Structure share ownership has a positive and significant impact on financial performance where the largest owner is owned by the government and will have an impact on the financial performance generated by management. Wahyudi and Pawesti's research (2006) was accepted by researchers who stated that ownership structure was able to influence the company's operational course and influence the company's performance in achieving its goal of maximizing company value.

Financial performance has a positive and significant influence ongoing concern audit opinion. The researcher accepts Susanto's research (2009) which states that the information given to investors about financial ratios as a tool to predict the survival of a company's, is expressed in the form of auditor opinion, then management to improve the company's performance and by looking at the financial condition and the company's ability to pay off debt. 
Government and managerial ownership structures have a negative and significant influence on the value of the company. Researchers reject Sugiharto and Moehaditoyo (2016) showing that managerial ownership has a positive and significant influence on firm value.

The financial performance with GPM indicators and fixed asset turnover has a positive and significant effect on the value of the company in terms of EPS, PBV, and Tobin's Q will increase. The researcher accepted the study of Ukhriyawati, Ratnawati, and Riyadi (2017) and Dwipartha and Witha (2013), which shows the financial performance of a company's value has a positive and significant influence.

The going concern auditing opinion with the Top 4 Public Accounting Firms, ROE, and ROA has a positive and significant influence on the company's value in EPS, PBV, and Tobin's Q.

\section{Theoretical Implications}

The company aims to increase net income resulting from operational activities including SOEs to optimize the value of the firm and the welfare of shareholders. Share price is as a representation of the value of a tradable company in obtaining capital gains. Internal factors and external factors are often used as a basis for investors in the capital market in taking investment decisions.

Maximizing the value of the firm is influenced by the management control that regulates the company's activity in paying dividends. The determination of value of the firm is influenced by financial performance factor, ownership structure factor and going concern audit opinion factor, macro and micro fundamental factor and several other factors outside of research object.

\section{Managerial Implications}

Economic exposure gives effect to the ownership structure where the government as the holder of state control can determine the policy and role for the SOEs in welfare of Indonesian society. Economic exposure affects the value of the firm shown by the risk in managing the financial through financial performance in order to increase the value of the firm and investment decisions.

Economic exposure affects the financial performance of management considering the SOEs established for the development of the state and people in the fields of health, mining, services and transportation, transportation and telecommunications, housing and infrastructure development required by all Indonesian people. Economic exposure affects going concern audit opinion in providing certainty of corporate financial records in accordance with accounting standards performed accountant.

The value of the firm in the eyes of investors as a consideration of the company's operational activities reflected in the trusted public accounting firm in providing auditor's opinion for the sake of the company's future survival and performance accountability of the management of SOEs.

\section{Implications for Economics}

The implications in the development of economics are to contribute to the study of value of the firm that connects the structure of ownership, financial performance, going concern audit opinion, and macro and micro fundamentals in economic decision making by management, government, and investors; the value of the firm can meet the needs and welfare for investors, the government, and the welfare of society and the value of the firm becomes the determinant of the development of the Indonesian economy in accordance with the objectives of the SOEs company which was established. 


\section{Conclusions and Suggestions}

\section{Conclusion}

Based on data analysis that has been done, all hypothesis testing of research which show influence with significant level of 5\% with t-table 1.960 except macro fundamental influence 0.0031421 and not significant equal to 1.914374 so rejected (H5) and macro fundamentals have effects 0.040271 and not significant at 1.674420 so rejected (H7).

\section{Suggestion}

Suggestions that can be submitted to the next researcher is able to examine the continuation of the value of the company outside the SOEs, can use the same variable with different indicators about the value of the firm, can use different variables that can affect the value of the firm, and can make reference remember lack of research.

\section{References}

Arvianto, R. A., \& Sabi, S. T. (2014). Pengaruh Faktor Fundamental Makro dan Mikro Terhadap Nilai Perusahaan (Studi pada Saham Perusahaan Sektor Perdagangan, Jasa dan Investasi yang Terdaftar di BEI periode 2010-2012). Jurnal Administrasi Bisnis (JAB), 13(1), 1-10.

Boynton, W. C., \& Raymond, N. J. (2005). Modern auditing: Assurance services and the integrity of financial reporting (8th ed.). New Jersey: Wiley.

Bowman, C., \& Ambrosini, V. (2007). Firm value creation and levels of strategy. Management Decision, 45(3), $360-371$.

Brigham, E. F., \& Houston, J. F. (2015). Dasar-Dasar Manajemen Keuangan. Essitials of financial manajement. Jakarta: Salemba Empat. Cheng, C. S. A., Lee, B.-S., \& Yang, S. (2012). The value relevance of earnings levels in the return-earnings relation. International Journal of Accounting and Information Management, 21(4), 260-284.

Claude, S. B., \& Labelle, F. R. (2012). Corporate governance mechanisms, accounting results and stock valuation in Canada. International Journal of Managerial Finance, 8(4), 332-343.

David, F. R. (2003). Strategic management: Concepts (9th ed.). Upper Saddle River, New Jersey: Prentice Hall.

Dowling, J., \& Pfeffer, J. (1975). Organizational legitimacy: Social values and organizational behavior. Pacific Sociological Review, 18, 122-136.

Dwipartha, N., \& Witha, M. (2013). Pengaruh Faktor Ekonomi Makro dan Kinerja Keuangan Terhadap Nilai Perusahaan Manufaktur di Bursa Efek Indonesia. E-Jurnal Ekonomi dan Bisnis Universitas Udayana, 2(4), 226-248.

Eduardus, T. (1997). Determinants of systematic risk: The experience of some Indonesian common stock. Kelola, Gadjah Mada University Business Review, No. 16/VI/1997.

Fama, E. F. (1978). The effect of a firm investment and financing decision on the welfare of its security holders. American Economic Review, 68, 272-280.

Fuller, R. J., \& Farrell, J. L. Jr. (1987). Modern investments and security analysis. Singapore: McGraw-Hill, International Editions Financial Series.

Hardaningtyas, P. K. (2014). Pengaruh Faktor Fundamental Mikro Makro Terhadap Harga Saham Perusahaan Semen Go Public. Jurnal Ilmu \& Riset Manajemen, 3(10), 1-16.

Jensen, M. C., \& Meckling, W. H. (1976). Theory of the firm: Managerial behavior, agency costs and ownership structure. Journal of Financial Economics, 13, 305-360.

Luo, X. M., Zhang, J., \& Duan, W. J. (2013). Social media and firm equity value. 2013. Information Systems Research, 24(1), 146-163. ISSN 1047-7047 (print). ISSN 1526-5536 (online).

McConnell, J. J., \& Muscarela, C. J. (1985). Corporate capital expenditure decisions and the market value of the firm. Journal of Financial Economics, 14, 399-422.

Morris, R. D. (1987). Signalling, agency theory and accounting policy choice. Journal Accounting and Business Research, 18(69), 47-56.

Opod., C. R. (2015). Analisis Pengaruh Faktor-Faktor Fundamental Makroekonomi Terhadap Kinerja Keuangan Perusahaan Serta Nilai Perusahaan (Studi Kasus Pada Perusahaan Perbankan Yang Terdaftar Di BEI Periode 2009-2013). Jurnal Riset Bisnis dan manajemen, 3(2), 127-140. 
Pater, A. D., \& Saifi, M. (2014). Faktor Internal Dan Eksternal Yang Mempengaruhi Pergerakan Harga Saham (Studi Pada Saham-Saham Indeks LQ45 Periode 2009-2013). Jurnal Administrasi Bisnis (JAB), 11(1).

Putra, N. W. A. (2014). Pengaruh Faktor Fundamental Pada Nilai Perusahaan Sektor Telekomunikasi Di Bursa Efek Indonesia. E-Jurnal Akuntansi Universitas Udayana, 8(3), 385-407.

Sirmon, D. G., Hitt, M. A., \& Ireland, R. D. (2007). Managing firm resources in dynamic environments to create value: Looking inside the black box. Academy of Management Review, 32(1), 273-292.

Spence, M. (1973). Job market signaling. The Quarterly Journal of Economics, 87(3), 355-374.

Sugiharto, T. R., \& Moehaditoyo, S. H. (2016). Risk management mediates the influence of good corporate governance, managerial shareholder, and leverage on firm value. IOSR Journal of Business and Management (IOSR-JBM), 18(11), 62-70. E-ISSN 2278-478X. P-ISSN 2319-7668.

Susanto, Y. K. (2009). Faktor-Faktor Yang Mempengaruhi Penerimaan Opini Audit Going Concern. Jurnal Bisnis Dan Akuntansi, $11(3), 155-173$.

Syahib, N. (2000). Analisis Pengaruh Beberapa Faktor Fundamental dan Risiko Sistematik Terhadap Harga Saham (Kasus Industri Barang Konsumsi yang Go-Publik di Pasar Modal Indonesia). Jurnal Ekonomi dan Bisnis Indonesia, 15(3), $294-312$.

Ukhriyawati, C. F., Ratnawati, T., \& Riyadi, S. (2017). The influence of asset structure, capital structure, risk management and good corporate governance of financial performance and value of the firm through earnings and free cash flow as an intervening variable in banking companies listed in Indonesia stock exchange. International Journal of Business and Management, 12(8), 249-260. ISSN 1833-3850. E-ISSN 1833-8119.

Wahyudi, U., \& Prawesti, H. P. (2006). Implikasi Kepemilikan Terhadap Nilai Perusahaan Dengan Keputusan Keuangan Sebagai Variabel Intervening. In Simposium Nasional Akuntansi IX (pp. 23-26). Padang.

Wardhani, R. (2006). MekanismeCorporate Governance dalam perusahaan yang Mengalami Masalah Keuangan (Financially Distressed firms). In Simposium Nasional Akuntansi IX (pp. 23-26). Padang. 